\title{
ANALISIS YURIDIS PEMBERIAN KREDIT DENGAN JAMINAN SURAT KEPUTUSAN PENSIUN OLEH \\ PT. BANK TABUNGAN PENSIUNAN NASIONAL, Tbk CABANG KEDIRI JAWA TIMUR
}

\author{
Yagus Suyadi ${ }^{1}$, Aulia Rahman Hakim ${ }^{2}$ \\ 1. Universitas Islam Kadiri, Kediri \\ 2. PT. Bank Tabungan Pensiunan Negara
}

\begin{abstract}
ABSTRAK
Penelitian ini bertujuan untuk : 1) Untuk mengetahui cara pengaturan dan prosedur pengikatan Surat Keputusan Pensiun sebagai jaminan kredit pensiunan di Bank BTPN Cabang Kediri yang dilakukan oleh pihak bank dengan pensiunan yang ditinjau dari hukum perikatan sebagaimana diatur dalam KUHPerdata. 2) Untuk mengetahui bentuk perlindungan hukum pensiunan PNS dalam perjanjian kredit dengan jaminan Surat Keputusan Pensiun di Bank BTPN Cabang Kediri apabila terjadi force majeur.

Metode pendekatan yang digunakan dalam penelitian ini adalah yuridis-empiris. Metode pendekatan yuridis empiris, yaitu suatu pendekatan pendekatan yuridis untuk menganalisis berbagai peraturan perundang- undangan yang berhubungan dengan pelaksanaan perjanjian kredit dengan jaminan Surat Keputusan Pensiun.

Hasil dari penelitian ini mengungkapkan bahwa pengikatan perjanjian kredit pensiun dan penyimpanan Surat Keputusan Pensiun sebagai dokumen kredit pensiun tidak menyalahi hukum perikatan. Hal ini dikarenakan Jaminan Surat Keputusan Pensiun PNS dapat dikatakan merupakan sebuah jaminan istimewa karena tidak termasuk jaminan fidusia, hak tanggungan maupun hipotek. Kredit yang dijaminkan sebenarnya adalah manfaat pensiun yang diterima pensiunan yang mengambil kredit pensiun ini, oleh karena itu resiko tentang terjadinya force majeuryang dialami oleh debitur tidaklah berpengaruh terhadap kewajiban mengangsur kredit setiap bulannya.

Kata kunci : kredit ; pensiun ; force majeur.
\end{abstract}

\section{A. PENDAHULUAN}

Pengertian hutang-piutang sehari-hari sering kita dengar dalam kehidupan bermasyarakat, hutang adalah pinjaman sejumlah uang kepada orang (lain), dan hutang orang (lain) kepada kita. Hutang piutang adalah wilayah koridor hukum perdata, yakni aturan yang mengatur hubungan antara orang yang satu dengan orang yang lainnya, dengan menitikberatkan pada kepentingan perorangan atau pribadi. Hutang - Piutang dianggap sah secara hukum apabila dibuat suatu perjanjian. Yakni perjanjian yang berdasarkan hukum yang diatur pada Pasal 1320 KUHPerdata, meliputi antara lain :

1. Sepakat mereka yang mengikatkan dirinya yaitu Bahwa semua pihak menyetujui materi yang diperjanjikan, tidak ada paksaan atau dibawah tekanan.

2. Cakap untuk membuat perjanjian yaitu Kata mampu dalam hal ini adalah bahwa para pihak telah dewasa, tidak dibawah pengawasan karena prerilaku yang tidak stabil dan bukan orang-orang yang dalam undang-undang dilarang membuat suatu perjanjian tertentu.

3. Mengenai suatu hal tertentu yaitu Perjanjian yang dilakukan menyangkut obyek hal yang jelas.

4. Suatu sebab yang halal Adalah bahwa perjanjian dilakukan dengan itikad baik bukan ditujukan untuk suatu kejahatan.

Terlepas dari 4 point itu maka perjanjian dapat dibatalkan dan batal demi hukum. Syarat pertama dan kedua menyangkut subyektif, sedangkan syarat ketiga dan keempat mengenai obyek. Terdapatnya cacat kehendak (keliru, paksaan, penipuan) atau tidak cakap untuk membuat perikatan, mengenai subyek mengakibatkan perjanjian dapat dibatalkan. Sementara apabila syarat ketiga dan keempat mengenai obyek tidak terpenuhi, maka perjanjian batal demi hukum.

Perjanjian hutang piutang yang salah satu pihak sebagai debitur adalah pensiunan pegawai negeri sipil. Disisi lain perlu mendapat perhatian adalah masa jabatan Pegawai Negeri Sipil (PNS) ditentukan sesuai dengan ketentuan 
undang-undang yang berlaku, menyadari peranan pegawai negeri yang demikian pentingnya, maka pemerintah memberikan beberapa hak tertentu kepada pegawai negeri, antara lain hak atas gaji, hak atas cuti, dan hak atas pensiun. Hal ini diterangkan di dalam Undang-Undang Nomor 43 Tahun 1999 tentang Perubahan Atas Undang-Undang Nomor 8 Tahun 1974 tentang Pokok-Pokok Kepegawaian Pasal 23. Dalam Undang-Undang tersebut tidak disebutkan arti pensiun, tetapi dilihat dari ketentuan Pasal 23 ayat 2 poin $b$ maka pensiun dapat diartikan batas akhir usia kerja dari PNS. Oleh karena dalam pensiun PNS diberhentikan dengan hormat karena usia kerja yang telah selesai maka para pensiunan PNS berhak atas tunjangan pensiun bagi PNS yang besarnya ditentukan sesuai golongan selama PNS tersebut menjabat. Hal ini dituangkan dalam keputusan pensiun yang dikeluarkan oleh pemerintah. Surat Keputusan Pensiun tersebut keberadaannya sejajar dengan Surat Keputusan Pengangkatan PNS yang juga dapat dijadikan jaminan dalam memperoleh kredit dari lembaga pembiayaan yang ada di Indonesia.

Tidak semua lembaga pembiayaan di Indonesia dapat menerima Surat Keputusan Pensiun sebagai jaminan dalam memperoleh kredit. Hanya lembaga pembiayaan resmi atau yang telah menjalin Perjanjian Kerja Sama dengan Dana Pensiun (Dapen) saja yang dapat menerima Surat Keputusan Pensiun sebagai jaminan untuk memperoleh kredit. Salah satu lembaga pembiayaan resmi yang dapat menerima Surat Keputusan Pensiun sebagai jaminan kredit adalah pada bank umum milik pemerintah serta pada PT. Bank Tabungan Pensiunan Nasional, Tbk (Bank BTPN).

Perjanjian hutang piutang yang disertai dengan suatu perjanjian dengan jaminan. Jaminan yang dimaksud perlu mendapat perhatian dengan berbagai perkembangan dan kebutuhan masyarakat sebagai pihak yang melakukan perjanjian dengan jaminan, kita telah melihat di depan bahwa masalah hak-hak jaminan berkaitan erat dengan masalah eksekusi apabila di kemudian hari terdapat wanprestasi atas pelunasan suatu piutang dari kreditur. Sehubungan dengan adanya dengan eksekusi tersebut kiranya logis, bahwa benda-benda jaminan seharusnya merupakan benda yang bisa dipindahtangankan, sebab suatu eksekusi pada hakikatnya merupakan pemindahtanganan benda jaminan dari pemilik kepada pembeli.

Penjaminan Surat Keputusan Pensiun sebagai agunan untuk memperoleh kredit sebelumnya dilakukan dalam perjanjian hutang hutang piutang atau perjanjian kredit atau perjanjian pinjam meminjam yang didalamnya terdapat hak dan kewajiban dari bank sebagai kreditur dan pihak pensiunan pegawai negeri sebagai debitur. Adapun definisi dari perjanjian kredit atau perjanjian pinjam meminjam terdapat dalam pasal 1754 KUHPerdata yaitu suatu perjanjian dengan mana pihak yang satu memberikan kepada pihak yang lain suatu jumlah tertentu barang-barang yang bisa habis karena pemakaian, dengan syarat bahwa pihak yang terakhir ini akan mengembalikan sejumlah yang sama dari jenis dan mutu yang sama pula. ${ }^{1}$

Unsur jaminan paling tidak meyakinkan dari pihak kreditur terhadap debitur dapat mengembalikan hutangnya sesuai yang diperjanjikan merupakan unsur yang sangat penting di dalam setiap perjanjian kredit. Kepercayaan kreditur menjadi unsur utama timbulnya suatu perjanjian hutang piutang, sedangkan jaminan adalah merupakan komitmen atau pernyataan dari kreditur atas jaminan pelunasan hutang yang diperjanjikan kepada kreditur, sehingga perjanian hutang piutang pada hakekatnya adanya kepercayaan dari debitur dan kreditur yang dilandasi dengan itikad baik untuk melakyukan perjanjian hutang piutang.

Perjanjian hutang piutang dengan jaminan berupa Surat Keputusan Pensiun dilaksanakan dengan tata cara pemenuhan piutang kreditur atau dalam masyarakat biasa disebut dengan pengembalian kredit oleh debitur atau pensiunan adalah dengan cara membayar angsuran yang dipotong langsung dari manfaat pensiun setiap bulannya. Sehubungan dengan adanya perjanjian kredit yang berlangsung antara pemberi kredit (Bank BTPN) dengan penerima kredit (Pensiunan PNS) disamping hak dan kewajiban yang timbul dengan adanya perjanjian kredit tersebut serta hambatan-hambatan yang mungkin timbul dengan adanya perjanjian kredit tersebut dalam melakukan perbuatan hukum, maka harus ada kesepakatan tertulis dengan Surat Keputusan Pensiun yang dapat dijadikan jaminan, sehingga

1 R. Subekti, 1995, Aneka Perjanjian, PT. Citra Aditia Bakti, Bandung, hal. 125. 
ada ketegasan dan kepastian hukum antara keduanya.

Dalam praktek sehari-hari di Bank BTPN Cabang Kediri menjalankan bisnis pensiunan berupa perjanjian kredit pensiun dengan jaminan Surat Keputusan Pensiun merupakan hal yang penting untuk memperoleh kredit pensiun khususnya di Bank BTPN selaku kreditur, yang secara tidak langsung merupakan sarana untuk modal ekonomi bagi para pensiunan dalam mempertahankan kehidupan atau meningkatkan kesejahteraan hidupnya.

Berdasarkan pada uraian latar belakang tersebut, mendorong penulis untuk mengkaji lebih lanjut dan mendalam mengenai permasalahan tersebut di atas dengan judul: ANALISIS YURIDIS PEMBERIAN KREDIT DENGAN JAMINAN SURAT KEPUTUSAN PENSIUN OLEH PT. BANK TABUNGAN PENSIUNAN NASIONAL, Tbk CABANG KEDIRI JAWA TIMUR.

Berdasarkan latar belakang di atas, dirumuskan beberapa permasalahan pokok yang akan dibahas dalam tesis ini, antara lain :

1. Bagaimana pengaturan dan prosedur pengikatan Surat Keputusan Pensiun sebagai jaminan kredit pensiunan di Bank BTPN Cabang Kediri ditinjau dari hukum perikatan sebagaimana diatur dalam KUH Perdata?

2. Bagaimana perlindungan hukum terhadap para pensiunan PNS (debitur) dalam melakukan perjanjian kredit dengan jaminan Surat Keputusan Pensiun di Bank BTPN Cabang Kediri selaku kreditur apabila terjadi force majeur?

Sesuai dengan latar belakang dan permasalahan di atas, maka penelitian ini bertujuan sebagai berikut :

1. Untuk mengetahui cara pengaturan dan prosedur pengikatan Surat Keputusan Pensiun sebagai jaminan kredit pensiunan di Bank BTPN Cabang Kediri yang dilakukan oleh pihak bank dengan pensiunan yang ditinjau dari hukum perikatan sebagaimana diatur dalam KUH Perdata.

2. Untuk mengetahui bentuk perlindungan hukum para pensiunan PNS dalam perjanjian kredit pensiun dengan jaminan Surat Keputusan Pensiun di Bank BTPN Cabang Kediri apabila peristiwa force majeurterjadi.

\section{B. METODOLOGI PENELITIAN.}

Berdasakan perumusan masalah dalam menyusun penelitian ini, jenis penelitian yang digunakan adalah penilitian hukum normatif. Sifat penelitian ini adalah penelitian deskriptif analitis. Penelitian deskriptif analitis merupakan penelitian yang berusaha mendeskripsikan dan menginterpretasikan sesuatu, misalnya kondisi atau hubungan yang ada, pendapat yang berkembang, proses yang sedang berlangsung, akibat atau efek yang terjadi, atau tentang kecendrungan yang tengah berlangsung kemudian dianalisis dan dilakukan pengambilan kesimpulan. ${ }^{2}$

\section{Metode Pendekatan.}

Metode pendekatan yang digunakan dalam penelitian ini adalah yuridis-empiris. Metode pendekatan yuridis empiris, yaitu suatu pendekatan yang meneliti data sekunder terlebih dahulu dan kemudian dilanjutkan dengan mengadakan penelitian data primer di lapangan. ${ }^{3}$

Metode pendekatan yuridis ini digunakan untuk menganalisis berbagai peraturan perundang-undangan yang berhubungan antara pelaksanaan perjanjian kredit dengan jaminan Surat Keputusan Pensiun. Sedangkan pendekatan empiris digunakan untuk menganalisis hukum bukan semata-mata sebagai perangkat peraturan perundang-undangan yang bersifat Normatif, tetapi hukum dilihat sebagai perilaku masyarakat (Pensiunan PNS) yang menggejala dalam kehidupan masyarakat.

2. Spesifikasi Penelitian.

Spesifikasi penelitian yang digunakan adalah secara deskriptif analitis, yaitu menggambarkan peraturan perundangundangan yang berlaku dikaitkan dengan teoriteori hukum dan praktek pelaksanaan hukum positif yang menyangkut permasalahan tersebut di atas.

3. Lokasi Penelitian.

Lokasi yang diambil untuk penelitian mengenai pelaksanaan perjanjian kredit dengan jaminan Surat Keputusan Pensiun yaitu pada Bank BTPN Cabang Kediri Jawa Timur. Bank BTPN Kediri beralamatkan di Jalan Brigjen

\footnotetext{
2 Peter Mahmud Marzuki, 2005, Penelitian
}

Hukum, Prenada Media, Jakarta, hal.35

$3 \longrightarrow$ dan Sri Mamudji, 1985,

Penelitian Hukum Nomatif Suatu Tinjauan Singkat, Rajawali Press, Jakarta, hal. 7 
Katamso No 32-34 Kelurahan Kampungdalem Kecamatan Kota Kota Kediri Propinsi Jawa Timur Kodepos 64126.

4. Populasi dan Sampel.

Populasi dalam penelitian ini adalah semua pihak yang terkait dengan pelaksanaan perjanjian kredit dengan jaminan Surat Keputusan Pensiun pada Bank BTPN Cabang Kediri Jawa Timur.

Pengambilan sampel ini menggunakan teknik purposive sampling, penarikan sample yang dilakukan dengan cara pengambilan subyek yang didasarkan dengan tujuan tertentu di mana tidak semua populasi akan diteliti, tetapi dipilih yang dianggap mewakili secara keseluruhan.

5. Jenis dan Sumber Data.

Jenis sumber data yang digunakan dalam penelitian ini adalah terdiri dari data primer dan data sekunder.

a. Data primer, adalah data yang diperoleh langsung dari sumbernya, dan dicatat untuk pertama kali. Dalam penelitian ini data primer dikumpulkan dengan cara wawancara, yaitu suatu percakapan, tanya jawab antara dua orang atau lebih yang duduk berhadapan secara fisik dan diarahkan pada suatu masalah tertentu. Wawancara juga dilakukan dengan para responden seperti tersebut dalam penentuan sampel di atas.

b. Data sekunder, adalah perolehan data dengan studi dokumen yang meliputi:

1) Bahan hukum primer, yaitu bahanbahan hukum yang bersifat mengikat yang terdiri dari :

- Kitab Undang-Undang Hukum Perdata

- Undang-Undang Nomor. 10 Tahun 1998 Atas Perubahan Undang-Undang Nomor 7 Tahun 1992 Tentang Perbankan

- Peraturan Perundangan yang berkaitan dengan :

- masalah perbankan

- masalah kredit

2) Bahan hukum sekunder, yang memberikan penjelasan mengenai bahan hukum primer, yaitu :

- Buku-buku tentang perjanjian kredit bank

- Buku-buku tentang perbankan

- Dokumen-dokumen perjanjian kredit
6. Metode Analisis Data

Penelitian ini merupakan penelitian yang bersifat deskriptif, maka penelitian ini menggunakan metode analisis kualitatif. Metode kualitatif adalah cara penelitian yang menghasilkan data deskriptif analisis, yaitu apa yang dinyatakan oleh responden secara tertulis atau lisan dan juga perilakunya yang nyata, diteliti, dan dipelajari sebagai sesuatu yang utuh kemudian ditarik suatu kesimpulan yang merupakan jawaban atas permasalahan yang diangkat dalam penelitian ini.

\section{HASIL PENELITIAN DAN PEMBAHASAN}

1. Pengaturan dan Prosedur Pengikatan Surat Keputusan Pensiun Sebagai Jaminan Kredit Pensiun di Bank BTPN Cabang Kediri Ditinjau dari Hukum Perikatan.

Prosedur Pengajuan Kredit Pensiun pada PT. Bank Tabungan Pensiun Nasional Tbk. (BTPN) Cabang Kediri adalah sebagai berikut:

a) Prosedur Permohonan/Pengajuan Kredit Pensiun.

Calon debitur datang ke PT. BTPN Tbk. Cabang Kediri dan menyerahkan dokumen persyaratan kredit pesiun kemudian Credit Acceptance memeriksa kelengkapan dokumen kredit pensiun. Credit Acceptance melakukan pemeriksaan dokumen dan sekaligus melakukan wawancara dengan nasabah. Jika dokumen persyaratan kredit memenuhi persyaratan Credit Acceptance menyerahkan aplikasi permohonan kredit pensiun untuk diisi dan ditandatangani calon debitur. Jika dokumen persyaratan tidak memenuhi persyaratan maka permohonan kredit belum bisa dilanjutkan sebelum dokumen kredit lengkap.

b) Prosedur Simulasi/Perhitungan Kredit Pensiun.

Credit Acceptance memeriksa keaslian dokumen persyaratan kredit pensiun kemudian melakukan simulasi/perhitungan kredit pensiun melalui program komputer. Calon debitur dapat menolak/menerima hasil perhitungan. Jika calon debitur menerima hasil perhitungan kredit pensiun Credit Acceptance melakukan wawancara terhadap calon debitur dan mencetak dokumen kredit, antara lain Analisa Pinjaman, Tes Wawancara Debitur, Memorandum Persetujuan Kredit dan Surat Pernyataan (jika diperlukan). 
Jika calon debitur menolak maka permohonan kredit pensiun tidak dapat dilanjutkan.

c) Prosedur Pembukaan Nomor Customer (CIF) dan Input Data Diri Calon Debitur.

Credit Acceptance melakukan pembukaan nomor customer bagi debitur yang mengajukan kredit pensiun dan menginput data diri beitur, data diri suami/istri dan data anak debitur melalui program komputer, kemudian memeriksa kembali kebenaran data yang diinput.

d) Prosedur Verifikasi Pinjaman Kredit Pensiun

Credit Acceptance memeriksa kembali keaslian dokumen persyaratan kredit pensiun, analisa pinjaman terkait plafond pinjaman, jangka waktu dan usia debitur serta memastikan hasil wawancara debitur telah sesuai standar yang hasilnya tercantum dalam Tes Wawancara Debitur. Jika dokumen persyaratan antara lain Analisa Pinjaman dan Tes Wawancara Debitur tidak memnuhi persyaratan maka permohonan kredit pensiun ditolak. Jika memenuhi persyaratan Credit Acceptance akan mencetak dokumen Surat Perjanjian Kredit (SPK) untuk ditandatangani debitur dan di otorisasi oleh Credit Acceptance Supervisor.

e) Prosedur Input Data Pinjaman.

Credit Acceptance memasukan nomor customer (CIF) dan menginput data pinjaman kredit pensiun per debitur melalui program komputer, kemudian mencetak Rincian Jadwal Angsuran (Payment Schedule) yang didalamnya tertera kode transaksi untuk computer Teller agar pinjaman kredit pensiun dapat dicairkan. Credit Admin Officer menginput datadata hasil penyimpanan kredit pensiun oleh Credit Acceptance dengan berpedoman dari data dokumen kredit dan data Credit Acceptance melalui program komputer dan credit admin merekap penyaluran kredit setiap harinya.

f) Prosedur Persetujuan Kredit Pensiun.

Branch Manager memeriksa isi dokumen Surat Perjanjian Kredit (SPK) terkait plafond pinjaman, jangka waktu dan usia debitur. Jika isi dokumen Surat Perjanjian Kredit (SPK) tidak wajar maka permohonan kredit ditolak. Jika isi dokumen Surat Perjanjian Kredit (SPK) wajar Branch Manager akan mentandatangani dokumen Surat Perjanjian Kredit (SPK) agar pinjaman kredit pensiun dapat dicairkan.

\section{g) Prosedur Pencairan Pinjaman}

Teller memasukan kode transaksi dalam system pencairan kredit melalui program komputer kemudian mencetak bukti pengeluaran kas. Teller menandatangani dan member stempel PAID pada dokumen Surat Perjanjian Kredit (Rincian Pinjaman) kemudian menyerahkan uang pinjaman kredit dan fotokopi lembar pertama Rincian Pinjaman kepada debitur. Teller mengarsip bukti pengeluaran kas berdasarkan tanggal transaksi.

Proses pemberian Kredit Pensiun pada

PT. Bank Tabungan Pensiun Nasional Tbk. (BTPN) Purna Bakti Cabang Kediri antara lain :

a. Pengajuan permohonan kredit oleh calon peminjam harus diawali dengan konsultasi kepada pihak yang mengurusi kredit yaitu pada bagian Credit Acceptance.

b. Melengkapi berkas-berkas persyaratan, yaitu Pemohon kredit harus melengkapi berkasberkas yang diminta oleh bagian kredit sesuai dengan ketentuan persyaratan yang berlaku terdiri dari persyaratan umum dan persyaratan khusus, serta dokumen yang digunakan.

Dokumen Inti dalam pemberian kredit pensiun di BTPN adalah Surat Keputusan Pensiun Asli dari nasabah yang mengajukan kredit. Surat Keputusan Pensiun Asli bisa disusulkan hanya dengan alasan : Surat Keputusan Pensiun masih sebagai jaminan kredit pensiun di bank lain dan proses kredit pensiun di Bank BTPN diajukan untuk menutup pinjaman pensiun di bank lain tersebut (take over).

Sedangkan Dokumen Pelengkap, antara lain :

a. Aplikasi permohonan yang dilengkapi dan ditandatangani debitur.

b. Foto copy KTP yang masih berlaku.

c. Dua lembar foto diri $4 \times 6$

d. Kartu keluarga

e. Foto copy kartu NPWP untuk keseluruhan pinjaman $>$ Rp. 50.000 .000 atau sesuai ketentuan yang berlaku.

f. Informasi uang pensiun terakhir, bisa bersumber dari foto copy carik, buku gaji atau buku tabungan dan sejenisnya.

Analisis Kredit, Menilai kelayakan kredit yang akan diberikan dengan dasar pertimbagan dari berkas pemohon seperti jumlah gaji pensiun, usia pensiun, jangka waktu, nominal kredit dan menguji keaslian dokumen.

$$
\text { Pemeriksaan keaslian dokumen }
$$
dilakukan dengan cara wawancara dengan 
nasabah, pemeriksaan fisik dokumen dan pencocokan data di Surat Keputusan Pensiun dengan Data yang ada di Dana Pensiun (DAPEN) seperti Taspen, Asabri, Dapenbun.

Pemeriksaan dokumen merupakan langkah awal yang perlu ketelitian, kecermatan, agar penyaluran kredit dapat lancar dan pemotongan manfaat pensiun debitur setiap bulannya dapat lancar sampai pinjaman lunas.

Wawancara, dilakukan dengan tujuan untuk mengetahu informasi data diri pensiunan sesuai dengan lembar wawancara dan keinginan kebutuhan pensiun yang sebenranya.

Keputusan perjanjian kredit dapat dicairkan atau ditolak berada di pejabat pemegang BWMK kredit, dalam hal ini adalah Branch Manager atau Credit Acceptance Supervisor. Sedangkan Keputusan dokumen kredit dapat diterima atau ditolak berada pada Credit Acceptance sebagai pemeriksa awal pengajuan kredit. Apabila Credit Acceptance merasa kurang yakin akan dokumen pengajuan kredit yang diajukan nasabah, Credit Acceptance dapat melakukan ekskalasi ke pimpinan, dalam hal ni Credit Acceptance Supervisor atau Branch Manager.

Credit Acceptance setelah melakukan simulasi kredit, menjelaskan ke nasabah mengenai rincian atas jumlah kredit yang diajukan, yaitu rincian tentang biaya kredit dan informasi pelunasan dipercepat apabila di tengah jalan debitur ingin melunasi pinjamannya. Credit Acceptance juga menjelaskan mengenai cover asuransi atas plafon kredit yang diajukan, mulai tentang besaran premi yang dibayarkan nasabah dimuka dengan dipotongkan langusng dari penerimaan kredit dan manfaat Asuransi.

Kredit sebelum dicairkan maka Credit Acceptance memberikan tanda terima Surat Keputusan Pensiun kepada nasabah, yang mana fungsinya untuk bukti penyimpanan Surat Keputusan Pensiun oleh dan di BTPN dan tanda terima jaminan SK dapat berfungsi untuk mengambil Surat Keputusan Pensiun oleh nasabah apabila pinjaman telah lunas. Selanjutnya Surat Keputusan Pensiun tersebut disimpan dalam brankas Jaminan oleh custodian kredit.

Penandatanganan akad kredit atau perjanjian kredit, Persetujuan kredit adalah pernyataan dari Credit Accpetance Supervisor bahwa kredit yang dimohon telah disetujui sesuai dengan perjanjian kredit.
Realisasi kredit, Pencairan dana yang dilakukan oleh Teller yang berupa pembayaran (uang) atau pemindah bukuan atas nama rekening peminjam.

Dari uraian diatas, maka dapat diketahui bahwasanya pengikatan perjanjian kredit pensiun dan penyimpanan Surat Keputusan Pensiun sebagai dokumen kredit pensiun tidak menyalahi dan tidak bertentangan dengan hukum perikatan.

Hal ini dikarenakan Jaminan Surat Keputusan Pensiun PNS dapat dikatakan merupakan sebuah jaminan istimewa karena tidak termasuk jaminan fidusia, hak tanggungan maupun hipotek. Hal ini diperjelas dengan Undang-Undang Nomor 42 Tahun 1999 Tentang Jaminan Fidusia, yang mana Surat Keputusan Pensiun PNS tidak memenuhi ciri dari Jaminan Fidusia yaitu dapat dieksekusi, serta pada Pasal 15 ayat (3) Undang-Undang Nomor 42 Tahun 1999 Tentang Jaminan Fidusia yang berbunyi apabila debitur cidera janji, penerima fidusia mempunyai hak untuk menjual benda yang menjadi objek Jaminan Fidusia atas kekuasaannya sendiri, dimana Surat Keputusan Pensiun Janda/Duda tidak dapat diperjual belikan, sehingga dapat dikatakan bukan termasuk Jaminan Fidusia.

Pihak BTPN dalam menerima objek jaminan berupa Surat Keputusan Pensiun lebih menekankan pada kepercayaan kepada calon debitur, dengan melihat asas-asas atau prinsipprinsip pemberian kredit, yaitu dilihat bahwa pihak debitur memenuhi prinsip yang dikenal dengan 5C yaitu Character (Watak/Kepribadian),Capacity (Kemampuan), Capital (Modal), Condition of Economy (Kondisi Perekonomian) dan Collateral (Jaminan/Agunan). Kepada calon debitur yang menggunakan objek jaminan berupa Surat Keputusan Pensiun PNS pihak bank menilai bahwa calon debitur berkepribadian baik, pihak bank dapat dengan mudah menghitung kemampuan keuangan calon debitur dari jumlah gaji yang tertera dalam Surat Keputusan Pensiun Pensiun tersebut, kemudian kredit yang dilakukan adalah kredit yang bersifat konsumtif dan tidak terlalu besar, serta pendapatan/gaji yangditerima oleh calon debitur yang bersifat tetap tidak terpengaruh pada perekonomian pasar. Sehingga pihak bank menyimpulkan bahwa Surat Keputusan Pensiun Pensiun adalah hak tagih yang berupa uang pensiun yang merupakan jaminan kebendaan yaitu berupa 
benda bergerak tak berwujud yang akan ada dan bersifat pasti.

\section{Perlindungan Hukum Debitur Jika Terjadi Force Majeur.}

Kita ketahui bahwasannya pengertian keadaan memaksa/force majeure adalah suatu keadaan dimana salah satu pihak dalam suatu perikatan tidak dapat memenuhi seluruh atau sebagian kewajibannya sesuai apa yang diperjanjikan, disebabkan adanya suatu peristiwa di luar kendali salah satu pihak yang tidak dapat diketahui atau tidak dapat diduga akan terjadi pada waktu membuat perikatan, di mana pihak yang tidak memenuhi kewajibannya ini tidak dapat dipersalahkan dan tidak harus menanggung risiko.

Pasal 1244 KUHPerdata dinyatakan bahwa : "Jika ada alasan untuk itu, si berhutang harus dihukum mengganti biaya, rugi dan bunga apabila ia tidak dapat membuktikan, bahwa hal tidak atau tidak pada waktu yang tepat dilaksanakannya perikatan itu, disebabkan karena suatu hal yang tidak terduga, pun tidak dapat dipertanggungjawabkan padanya. Kesemuanya itupun jika itikad buruk tidaklah ada pada pihaknya." dan Pasal 1245 KUHPerdata menyatakan bahwa : "Tidaklah biaya rugi dan bunga, harus digantinya, apabila lantaran keadaan memaksa atau lantaran suatu kejadian tidak disengaja si berhutang berhalangan memberikan atau berbuat sesuatu yang diwajibkan, atau lantaran hal-hal yang sama telah melakukan perbuatan yang terlarang."

Berdasarkan kedua pasal tersebut, maka ketentuan ini memberikan kelonggaran kepada debitur untuk tidak melakukan penggantian biaya, kerugian, dan bunga kepada kreditur, oleh karena suatu keadaan yang berada di luar kekuasaannya. ${ }^{4}$

Akan tetapi hal tersebut sebelumnya harus benar-benar dibuktikan mengenai force majeur yang dialaminya. Bahwasanya force majeur harus dapat masuk dalam kategori salah satu berikut ini :

1. Force majeur karena sebab-sebab yang tidak terduga.

Dalam hal ini, menurut Pasal 1244 KUHPerdata, jika terjadi hal-hal yang tidak terduga (pembuktiannya dipihak debitur) yang menyebabkan terjadinya kegagalan dalam

${ }^{4}$ Salim H.S, 2008, Hukum Kontrak, Teori dan Teknik Penyusunan Kontrak, Sinar Grafika, Jakarta, hal.101 melaksanakan kontrak, hal tersebut bukan termasuk dalam kategori wanprestasi kontrak, melainkan termasuk kedalam kategori force majeur, yang pengaturan hukumnya lain sama sekali. Kecuali jika debitur beriktikad jahat, dimana dalam hal ini debitur tetap dapat dimintakan tanggung jawabnya.

\section{Force majeur karena keadaan memaksa}

Sebab lain mengapa seseorang debitur dianggap dalam keadaan force majeur sehingga dia tidak perlu bertanggung jawab atas tidak dilaksanakannya kontrak adalah jika tidak dipenuhinya kontrak tersebut disebabkan oleh keadaan memaksa. 3. Force majeur karena perbuatan tersebut
dilarang
Apabila ternyata perbuatan (prestasi) yang harus dilakukan oleh debitur ternyata dilarang (oleh perundang-undangan yang berlaku), maka kepada debitur tersebut tidak terkena kewajiban membayar ganti rugi.

Dikarenakan dalam perjanjian kredit pensiunan yang dijaminkan sebenarnya adalah manfaat pensiun yang diterima pensiunan yang mengambil krdit pensiun ini, oleh karena itu resiko tentang terjadinya force majeur yang dialami oleh debitur tidaklah mempengaruhi tentang kewajiban mengangsur kredit setiap bulannya sebab angsuran kredit pinjaman ini langsung dipotong dari manfaat pensiun yang diterima pensiunan setiap bulannya.

Keadaan force mejeur kemungkinan bisa terjadi, apabila Dana Pensiun (DAPEN) para pensiunan yang terkena keadaan force majeur. Tetapi hal tersebut kemungkinan masih bisa diatasi dengan cara cover (talangan) dari kantor dana pensiun lainnya yang sama yang berada diluar daerah pensiunan dan hal ini tidak mempengaruhi tempat dimana para pensiunan mengambil manfaat pensiunan setiap bulannya.

\section{KESIMPULAN}

Berdasarkan penelitian dan pembahasan dari uraian permasalahan yang diteliti, maka dengan ini dapat disimpulkan bahwa :

1. Pengikatan perjanjian kredit pensiun dan penyimpanan Surat Keputusan Pensiun sebagai dokumen kredit pensiun tidak menyalahi aturan dan tidak bertentangan dengan hukum perikatan. Hal ini dikarenakan Jaminan Surat Keputusan Pensiun PNS dapat dikatakan merupakan sebuah jaminan istimewa karena tidak 
termasuk jaminan fidusia, hak tanggungan maupun hipotek. Hal ini diperjelas dengan Undang-Undang Nomor 42 Tahun 1999 Tentang Jaminan Fidusia, yang mana Surat Keputusan Pensiun PNS tidak memenuhi ciri dari Jaminan Fidusia yaitu dapat dieksekusi, serta pada Surat Keputusan Pensiun tidak dapat diperjual belikan, sehingga dapat dikatakan bukan termasuk Jaminan Fidusia.

2. Resiko tentang terjadinya force majeur yang dialami oleh debitur tidaklah mempengaruhi tentang kewajiban mengangsur kredit setiap bulannya sebab angsuran kredit pinjaman ini langsung dipotong dari manfaat pensiun yang diterima pensiunan setiap bulannya. Keadaan force mejeur kemungkinan bisa terjadi, apabila Dana Pensiun (DAPEN) yang dalam keadaan force majeur. Tetapi hal tersebut kemungkinan masih bisa diatasi dengan cara cover (talangan) dari kantor dana pensiun lainnya yang sama yang berada diluar daerah pensiunan dan hal ini tidak mempengaruhi tempat dimana para pensiunan mengambil manfaat pensiunan setiap bulannya.

\section{DAFTAR PUSTAKA}

Buku :

Badrulzaman, Mariam Darus, Perjanjian Kredit Bank, Alumni, Bandung, 1978. Perjanjian Baku Standart dan Perkembangannya di Indonesia, Alumni, Bandung, 1981.

Bako, Ronny Soetma, Hubungan Bank dan Nasabah Terhadap Produk Tabungan dan Deposito, PT. Citra Aditya Bhakti, Bandung, 1995. , Aneka Hukum Bisnis, Alumni, Bandung, 1994.

Djumhana, Muhamad, Hukum Perbankan di Indonesia, PT. Citra Aditya Bhakti, Bandung, 2000.

Hay, Marhainis Abdul, Hukum Perbankan Di Indonesia, Pradnya Paramita,Jakarta, 1979.

Kasmir, Bank dan Lembaga Keuangan Lainnya, PT. Raja Grafindo Persada, Jakarta, 2000.

Muhammad, Abdulkadir, Hukum Perikatan, PT. Citra Aditya Bhakti, Bandung,1993.
Mulyadi, Kartini, Gunawan Wijaya, Perikatan Yang Lahir Karena Perjanjian, PT. Raja Grafindo Persada, Jakarta, 2003.

Naja, Daeng, Hukum Kredit dan Bank Garansi, PT. Citra Aditya Bhakti, Bandung, 2005.

Patrik, Purwahid, Kashadi, Hukum Jaminan, Fakultas Hukum UNDIP, Semarang, 2004.

Poerwodaminto, W.J.S., Kamus Besar Bahasa Indonesia, Balai Pustaka, Jakarta, 1983.

Satrio, J, Hukum Perjanjian, PT. Citra Aditya Bhakti, 1993.

Sembiring, Sentosa, Hukum Perbankan, Mandar Maju Jaya, 2000.

Simorangkir, O.P., Kamus Perbankan, Bina Aksara, Bandung, 1989.

,Seluk Beluk Bank Komersial, Aksara Persada Indonesia, Jakarta, 1986.

Soekanto, Soerjono, Pengantar Penelitian Hukum, UI Press, Jakarta, 1986. , Sri Mahmudji, Penelitian Hukum Normatif Suatu Tinjauan Singkat, Rajawali Press, Jakarta, 1985.

Soebekti, Aneka Perjanjian, PT. Citra Aditya Bhakti, Bandung, 1992.

Aspek-Aspek Perikatan Nasional, Alumni, Bandung, 1986.

Jaminan-Jaminan Untuk Pemberian Kredit Menurut Hukum Indonesia, Alumni, Bandung, 1986.

Sugiono, Metode Penelitian Administrasi, Alfabeta, Bandung, 2001.

Sutan, Remy Sjahdeni, Kebebasan Berkontrak Dan Perlindungan Yang Seimbang Bagi Pihak Dalam Perjanjian Kredit di Indonesia, Institut Bankir Indonesia, Jakarta, 1993.

Suyatno dkk, Thomas, Dasar-Dasar Perkreditan, PT. Gramedia Pustaka Utama, Jakarta, 1997.

Syahrani, Ridwan, Seluk Beluk Dan Asas-asas Hukum Perdata, Alumni, Bandung, 2000.

Tri Santoso, Ruddy, Kredit Usaha Perbankan, Andi, Yogyakarta, 1996.

Untung, Budi, Kredit Perbankan di Indonesia, Andi, Yogyakarta, 2005.

Widjanarto, Hukum dan Ketentuan Perbankan di Indonesia, Pustaka Utama Grafiti, 2003. 
Wijaya, Gunawan, Ahmad Yani, Jaminan Fiducia, PT. Raja Grafindo Persada, Jakarta, 2000.

\section{Peraturan Perundang-Undangan :}

Kitab Undang-Undang Hukum Perdata.

Undang-Undang Nomor 11 Tahun 1969 tentang Pensiun Pegawai dan Pensiun Janda/Duda Pegawai.

Undang-Undang Nomor 10 Tahun 1998 Atas Perubahan Undang-Undang Nomor 7 Tahun 1992 Tentang Perbankan.

Undang-Undang Nomor 23 Tahun 1999 Tentang Bank Indonesia.

Undang-Undang Nomor 43 Tahun 1999 Atas Perubahan Undang-Undang Nomor 8 Tahun 1974 Tentang Pokok-Pokok Kepegawaian.

Peraturan Pemerintah Nomor 96 Tahun 2000 Tentang Wewenang Pengangkatan, Pemindahan, Dan Pemberhentian Pegawai Negeri Sipil.

Peraturan Bank Indonesia Nomor 3/10/PBI/2001 Tentang Penerapan Prinsip Mengenal Nasabah Surat Keputusan Direksi Bank Indonesia Nomor 23/69/KEP/DIR Tentang Jaminan Pemberian Kredit. 